\title{
A STUDY ON RISK-TAKING BEHAVIOURS OF ADOLESCENTS AND THEIR PERCEPTION TOWARDS EFFECTS OF HOOKAH USE ON HEALTH ${ }^{(1)}$
}

\section{ERGENLERİN RISKK ALMA DAVRANIȘLARI İLE NARGILENIN SAĞLIĞA ETKILERINNE YÖNELIK ALGILARININ İNCELENMESI}

\author{
Hamide ZENGIN ${ }^{1}$, Nursan ÇINAR ${ }^{2}$ \\ ${ }^{1}$ Suluova State Hospital, Amasya. Sakarya University, Instutue of Health Science, Doctoral \\ Program, Department of Nursing, Sakarya / Turkey \\ ${ }^{2}$ Sakarya University, Faculty of Health Science, Department of Pediatric Nursing, \\ Sakarya / Turkey
}

ORCID ID: 0000-0002-2389-6466 ${ }^{1}$ 0000-0003-3151-9975²

\begin{abstract}
Öz: Amaç: Bu çalışmanın amacı ergenlerin olumsuz risk alma davranıșlarının ve nargilenin sağlığa etkileri ile ilgili algılarının belirlenmesi, aralarındaki ilişkinin incelenmesidir. Yöntem: Tanımlayıcı ve analitik olarak planlanan araştırma, Sakarya ilinde farklı sosyoekonomik düzeydeki on bir lisede Mart-Nisan 2015 tarihleri arasında yapıldı. Çalışmanın örneklemini gönüllü 900 lise öğrencisi oluşturdu. Araştırmada veriler araştırmacılar tarafindan hazırlanan soru formu, "Nargilenin Sağlığa Etkileri Algı Ölçeği" ve "Ergenlerde Kısa Heyecan Arayışı Ölçeğì" ile toplandı. Veriler bilgisayar ortamında SPSS 20 programında değerlendirildi. Bulgular: Çalışmaya katılan öğrencilerin \% 50,3' ünün kız, \% 49,7'sinin erkek olduğu ve \% 95,2' sinin ailesi ile birlikte yaşadığı saptandı. Araștırmaya katılan ergenlerin nargilenin sağlığa etkileri algı ölçeğinden aldıkları toplam puan ortalamasının $61,97 \pm 11,12$, ergenlerde kısa heyecan arayışı ölçeğinin toplam puan ortalamasinın 10,24 $\pm 3,92$ olduğu belirlendi. Nargilenin sağlığa etkileri algı ölçeği puanları ile kısa heyecan arayıșı ölçeği puanları arasında istatistiksel olarak anlamlı bir ilişki bulundu. Bu iliş̧ki çok güçlü olmamakla birlikte negatif yönde bir ilişsidir $(r=-0,204$ $\mathrm{p}=0.001$ ). Sonuç: Sigara içen ve nargile kullanan ergenlerin risk alma davranışlarının yüksek olduğu ve nargilenin sağlığa etkileri ile ilgili algılarının düşük olduğu saptandı. Ergenlerin nargilenin sağlığa etkileri ile algıları artıkça riskli davranışlara eğilimlerinin azaldığı tespit edildi.

Anahtar Kelimeler: Ergen, Sigara Kullanımı, Nargile Kullanımı, Sağlık Etkileri, Risk Alma Davranışı
\end{abstract}

Abstract: Introduction: The aim of this study is to determine the negative risk-taking behaviours of adolescents and their perceptions towards the effects of hookah use on health, and to evaluate the correlation between them. Methods: The study was conducted in eleven high schools at different socio-economic levels in Sakarya, Turkey between the dates of March-April 2015. The sample of the study included 900 high school students volunteering for the study. The study was descriptive and correlational. The data were collected via a questionnaire and two scales called "Perception Scale of Effects of Hookah use on Health" and "Brief Sensation Seeking Scale of Adults". Data were evaluated using SPSS 20 . Results: It was found out that $50.3 \%$ of the participants were women, $49.7 \%$ were men and $95.2 \%$ lived with their families. It was detected that total score averages for Brief Sensation Seeking Scale was $10.24 \pm 3.92$ and it was $61.97 \pm 11.12$ for Perception Scale of Effects of Hookah use on Health. There was a statistically significant correlation between Perception Scale of Effects of Hookah use on Health and Brief Sensation Seeking Scale of Adolescents. Though not a strong one, this correlation is negative $(r=-0.204 \quad \mathrm{p}=0.001)$. Conclusion: It was determined that adolescents smoking and using hookah had higher levels of risk-taking behaviours while they had lower perceptions towards effects of hookah use on health.

Key Words: Adolescent, Cigarette Use, Hookah Use, Health Effects, Risk-Taking Behaviour

Doi: $10.17363 / S S T B .2018 .29 .13$

(1) Corresponding Author: Nursan ÇINAR. Sakarya University, Faculty of Health Sciences, Sakarya / Turkey, ndede@ sakarya.edu.tr, Geliş Tarihi / Received: 20.09.2018, Kabul Tarihi / Accepted: 18.12.2018, Makalenin Türü: Type of article (Araştırma - Uygulama / Research -Application) Çıkar Çatışması / Conflict of Interest: Yok / None, Etik Kurul Raporu / Ethics Committee: Var / Yes "Sakarya University Faculty of Medicine Clinical Research Ethical Committee (Date/Number: 12/02/2015-1761; 71522473/050.01.04/13, Sakarya Provincial Directorate of National Education, Sakarya Governor's Office (Number: 11150731/160.01.01/2580938 Date: 09/03/2015.) 
International Refereed Academic Journal of Sports, Health and Medical Sciences October - November - December Issue: 29 Fall Winter Semester Year: 2018

Uluslararası Hakemli Akademik Spor Sağlık ve Tıp Bilimleri Dergisi Ekim - Kasım - Aralık Sayı: 29 Güz Kış Dönemi Yıl: 2018 ID:409 K:508

ISSN Print: 2146-8508 Online 2147-1711

(ISO 18001-OH-0090-13001706 / ISO 14001-EM-0090-13001706 / ISO 9001-QM-0090-13001706 / ISO 10002-CM-0090-13001706) (TRADEMARK)

\section{INTRODUCTION}

During the process of becoming an adult (Aras et al., 2007: 186-196) adolescents may exhibit risky behaviours with instant results which can have an impact on their adulthood health (Paulmann et al., 2011; Telef, 2014 :591-604). These behaviours can be listed as using tobacco, alcohol or drug, risky driving, crime trends and crime, early sexual onset, becoming distant from the family, school absenteeism and truancy, class apathy, social adjustment problems unhealthy diet and lack of activity (Aras et al., 2007: 186-196).

Sensation seeking is a personality trait believed to have a biological basis that expresses as a need for physiological arousal, novel experience, and a willingness to take social, physical, and financial risks to obtain such arousal (Bardo et al., 1996: 23-43). Sensation seeking is associated with a variety of illegal and/or risky behaviors such as the use of illicit drugs (Newcomb and McGee, 1991: 614-628; Palmgreen et al., 2001: 292-295; Stephenson et al., 2002: 23-43; Zuckerman et al., 1993: 757-768), sexual risk-taking (Donohew et al., 2000: 1079-1091; Hoyle et al., 2000: 1203-1231), reckless driving (Heino et al., 1996: 71-79), smoking (Zuckerman et al., 1990: 209-220), and alcohol use (Stacy et al., 1993: 1-24).
The studies conducted reveal that using tobacco products start at adolescence and that the rate of use increases as one grows older. Use of cigarette and other tobacco products during adolescence increases the probability of becoming a tobacco user in adulthood (Akter, 2011: 1-13).

Although the most frequently used tobacco product is the cigarette both in Turkey and in the World, it is remarkable that hookah use is becoming more widespread in recent years (Alvur et al., 2014: :1977-1980; Cinar and Cakmak, 2014 :8005-8006; İbrahimov et al., 2012 :49-56; Peltzer and Pengpid, 2014 :10033-10038; Shaikh et al., 2012 :18191822). It is estimated that 100 million people a day use hookah throughout the World (Alzohairy, 2012 :45-57; All Naggar and Saghir, 2011: 3041-3047 ; Cinar and Cakmak, 2014 :8005-8006; İbrahimov et al., 2012 :49-56).

Using tobacco products and its addiction may cause fatal illnesses (Bhagabaty et al., 2015 :811-814; Crawford, et al., 2012 :4733-4738; Okagua et al., 2015: 19-24; Patel et al., 2012 :4173-4176; Sezer and Picak, 2011: 133-143; Maziak, 2013: 1-4). Nearly 5 million people die every year because of tobacco use and this number is estimated to reach 10 million in the next 20- 30 years (Alzohairy, 2012 :45-57; All Naggar and Saghir, 2011: 3041-3047; Patel et al., $2012: 4173-4176$;). 


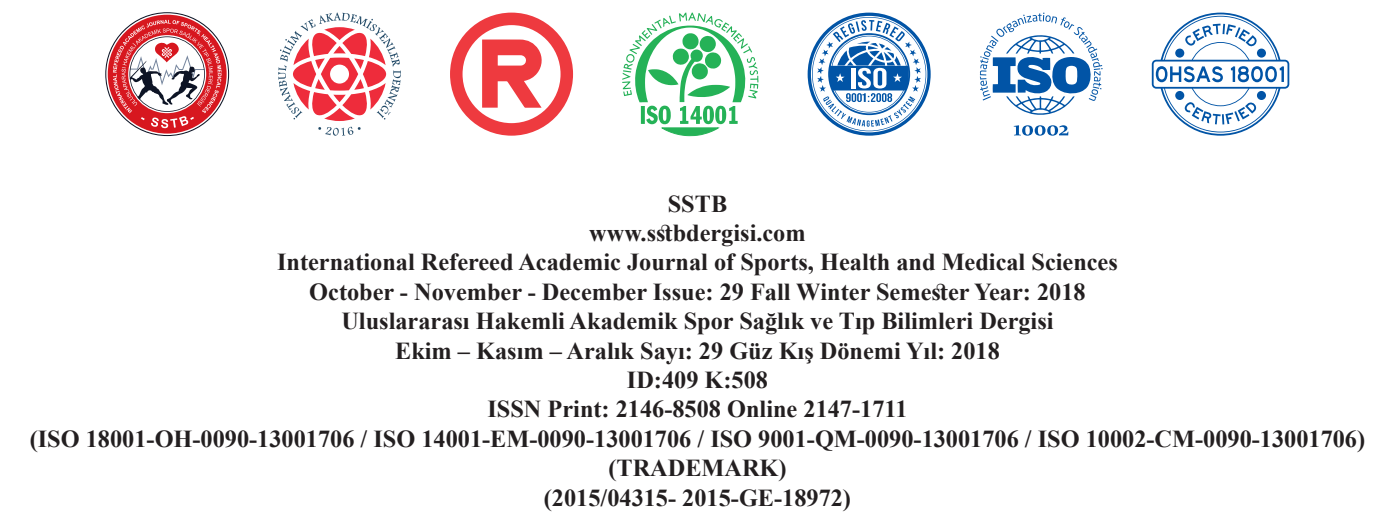

Being a different form of tobacco use, hookah is considered to be a global tobacco epidemic (Hassoy et al., 2011: 91-99) which has become more widespread among the youth till the beginning of the 21 st century (Kuntz and Lampert, 2015: 467-473; Palamar et al., 2014: 227-234; Maziak, 2013: 1-4).

Hookah smoking is often mistaken as a healthy smoking habit, primarily because society is ill-informed about the adverse health risks of hookah (Okdemir, 2013: 1-78). A significant number of adolescents do not perceive hookah as a tobacco product and misunderstand that smoking hookah does not involve any health risk (Akter, 2011: 1-13). A significant part of those who regularly or occasionally smoke hookah are not aware of the health risks of hookah (Bilir et al., 2010: 33-42). In another study, approximately onethird of the subjects misjudge that the adverse health risks of hookah smoking are less severe than the ones of cigarette smoking; about one fourth of the same group share the general misconception that hookah smokers are protected from harmful substances because the smoke is inhaled through the water chamber which filter out nicotine and other toxins in the hookah tobacco. (Hassoy et al., 2011: 91-99) In recent years, hookah smoking has become popular habit among adolescents (Özcebe, 2008: 374-377). Adolescents try hookah without being aware that it is a type of tobacco product and after some time they become addicted (Cakmak, 2014: 1-11; Cinar and Cakmak, 2014: 7; Alvur et al, 2014:19771980; Akter, 2011: 1-13). Hookah use is the most considerable gateway to nicotine addiction (Hassoy et al., 2011: 91-99).

This study aims to detect the negative risk taking behaviours of adolescents and their perceptions about the effects of hookah use on health, the correlation between their behaviours and perceptions, and to draw attention to the importance of this issue.

\section{METHOD and MATERIAL}

\section{Aim and Type of the Study}

The study was conducted as a descriptive and analytical one in order to determine the negative risk-taking behaviors of adolescents and their perception about health effects of hookah, and to examine the correlation between them.

\section{Research Consent}

The consent of study was obtained from Sakarya University Faculty of Medicine Clinical Research Ethical Committee. Necessary permits were also taken from Sakarya Provincial Directorate of National Education, Sakarya Governor's Office and school directorates. Students to be included in the study and their parents were informed about the study and the ones who volunteered were included in the study. 


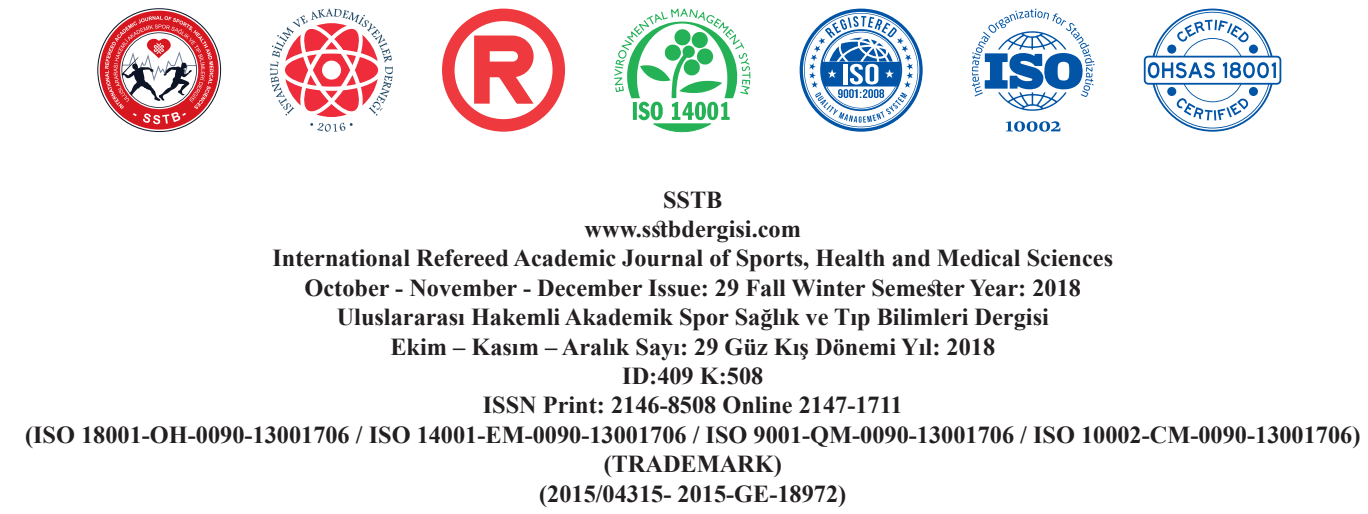

\section{Time and Place of the Study}

The data were collected from 11 high schools of different types in different socio-economic levels in Sakarya, a province in the Northwest of Turkey, between March-April 2015.

\section{Sample and Universe of the Study}

The sample of study consisted of 9th, 10th, 11th and 12th grade students at various high schools in Sakarya during the spring semester of 2014-2015 Academic Year. The whole list of high schools in the towns was also considered. Schools were chosen randomly. They were state schools of different types. The research was conducted among 9th, 10th 11 th and 12th grade students. In the calculation of sample size confidence interval was taken as $95 \%$. In determining the number of samples, the scale with the highest number of items was taken into consideration. Number of sample was found to be 750 by calculating 50 times of 15 items in the "Perception Scale of Effects of Hookah use on Health". Taking into account that there could be some missing data, the number of the sample was calculated as $20 \%$ more and a total of 900 people were given the questionnaire. 42 students who had missing information were excluded and the data from a total of 858 students were assessed. For the student selection from schools and classes, stratified sampling method was used. Stratum weight was found first using the formulae below, then number of students to be chosen were calculated (Celik, 2011: 195-196).

- (Stratum weight $=$ number of individuals in the stratum / number of population)

- $\quad$ number of individuals $=$ stratum weight $x$ sample volume chosen from the population)

The number of students to be included in the study was detected by simple random sampling, representing the layer they belong to.

\section{Student Selection Criteria}

Voluntary students, having no communicative problems, studying at $9^{\text {th }}, 10^{\text {th }}, 11^{\text {th }}$ and $12^{\text {th }}$ grades during the spring semester of 2014-2015 academic year.

\section{Data Collection Tools Used in the Study}

Questionnaire containing the individual characteristics and the introductory features of adolescents. The Questionnaire consisted of 33 questions. First 14 questions included demographic features (age, gender, height, weight, parents' education, school, classes, amount of weekly pocket money, the status of living with family, number of siblings, family income, and employment). Other questions were related to the use of tobacco and hookah.

\section{Perception scale of effects of hookah use} on health. It is a 5 point Likert Scale con- 
International Refereed Academic Journal of Sports, Health and Medical Sciences

October - November - December Issue: 29 Fall Winter Semester Year: 2018

Uluslararası Hakemli Akademik Spor Sağlık ve Tıp Bilimleri Dergisi

Ekim - Kasım - Aralık Sayı: 29 Güz Kış Dönemi Yıl: 2018 ID:409 K:508

ISSN Print: 2146-8508 Online 2147-1711

(ISO 18001-OH-0090-13001706 / ISO 14001-EM-0090-13001706 / ISO 9001-QM-0090-13001706 / ISO 10002-CM-0090-13001706) (TRADEMARK)

(2015/04315- 2015-GE-18972)

sisting of 15 items, which was developed and its validity and reliability were performed by Cinar and Cakmak in 2014. Each item is scored between 1 and 5, the scores depending on the answers (Cakmak, 2014: 19-21). Minimum score from the scale is 15 and the maximum is 75 . In the study by Cinar and Cakmak, Cronbach Alpha value of the scale was found as 0,93 . The high score is a sign of high perception about the effects of hookah use on health (Cakmak, 2014: 19-21).

\section{Brief sensation seeking scale for adoles-} cents: Developed by Stephenson, Hoyle, Palmgreen and Slater in 2003 (Stephenson et al., 2003: 279-286 ) and its reliability and validity in Turkish were performed by Celik, Turan and Gungor in 2014, this scale is a 4 point Likert Scale including 4 items, and its Cronbach Alpha value is 0,81 . Minimum score from the scale is 4 and the maximum is 16 . High scores from the scale show that the level of risk taking is high. There is no reverse coding (Celik et al., 2014: 207-208).

\section{Collection of Data}

Prior to the administration of questionnaires, school principals were negotiated to decide on the time and place of data collection. Students were informed about the survey, voluntary ones were picked up by using simple random number charts. Data were collected by the researcher accompanied by a Psycho- logical Consultancy and Guidance (PCG) teacher. After data collection, the students who participated in the study were given a booklet titled "Health Hazards of Smoking and Hookah Training Manual".

\section{Analysis of Data}

Collected data were transferred to a computer and evaluated using SPSS 20 Statistical program. Socio demographical data, Perception Scale of Effects of Hookah use on Health and Brief Sensation Seeking Scale for Adolescents were evaluated using number and percentage. When evaluating the differences between the groups, Mann-Whitney $U$ and Kruskal Wallis-H tests were used. Since the unit numbers were more than 20, standardized $\mathrm{z}$ value was given for Mann-Whitney U test. In the event of significant difference in Kruskal Wallis-H test, the groups having difference were detected by Post-Hoc Multiple Comparison Test. While studying the correlation between the scales, it was seen that the scores did not follow the normal distribution, so Spearman's Correlation Coefficient was made use of. Significance level (p) was taken as 0,$05 ; \mathrm{p}<0,05$ meant that there was a significant correlation/difference while $p>0,05$ meant no significant correlation/difference.

\section{FINDINGS}

Data of 858 participants were analysed at the end of the survey. 
SSTB

www.sstbdergisi.com

International Refereed Academic Journal of Sports, Health and Medical Sciences October - November - December Issue: 29 Fall Winter Semester Year: 2018

Uluslararası Hakemli Akademik Spor Sağlık ve Tıp Bilimleri Dergisi Ekim - Kasım - Aralık Sayı: 29 Güz Kış Dönemi Yıl: 2018 ID:409 K:508

ISSN Print: 2146-8508 Online 2147-1711

(ISO 18001-OH-0090-13001706 / ISO 14001-EM-0090-13001706 / ISO 9001-QM-0090-13001706 / ISO 10002-CM-0090-13001706) (TRADEMARK)

(2015/04315- 2015-GE-18972)

Table 1. Descriptive Features of Adolescents

\begin{tabular}{|c|c|c|}
\hline Descriptive Features & $\mathrm{n}$ & $\%$ \\
\hline \multicolumn{3}{|l|}{ Age Group } \\
\hline 15 and younger & 259 & 30,2 \\
\hline 16 & 254 & 29,6 \\
\hline 17 & 218 & 25,4 \\
\hline 18 and older & 127 & 14,8 \\
\hline \multicolumn{3}{|l|}{ Gender } \\
\hline Male & 426 & 49,7 \\
\hline Female & 432 & 50,3 \\
\hline \multicolumn{3}{|l|}{ School } \\
\hline High School & 84 & 9,8 \\
\hline Anatolian High School & 131 & 15,3 \\
\hline Science High School & 92 & 10,7 \\
\hline Vocational and Technical school & 502 & 58,5 \\
\hline Social Sciences School & 34 & 4 \\
\hline Fine Arts School & 15 & 1,7 \\
\hline \multicolumn{3}{|l|}{ Grade } \\
\hline 1 & 313 & 36,5 \\
\hline 2 & 198 & 23,1 \\
\hline 3 & 181 & 21,1 \\
\hline 4 & 166 & 19,3 \\
\hline \multicolumn{3}{|l|}{ Number of Siblings } \\
\hline $1-2$ & 435 & 50,7 \\
\hline $3-4$ & 379 & 44,2 \\
\hline $5-6$ & 36 & 4,2 \\
\hline 7 and more & 8 & 0,9 \\
\hline \multicolumn{3}{|l|}{ Living with the family } \\
\hline Yes & 817 & 95,2 \\
\hline
\end{tabular}


SSTB

www.sstbdergisi.com

International Refereed Academic Journal of Sports, Health and Medical Sciences

October - November - December Issue: 29 Fall Winter Semester Year: 2018

Uluslararası Hakemli Akademik Spor Sağlık ve Tıp Bilimleri Dergisi

Ekim - Kasım - Aralık Sayı: 29 Güz Kış Dönemi Yıı: 2018

ID:409 K:508

ISSN Print: 2146-8508 Online 2147-1711

(ISO 18001-OH-0090-13001706 / ISO 14001-EM-0090-13001706 / ISO 9001-QM-0090-13001706 / ISO 10002-CM-0090-13001706) (TRADEMARK)

(2015/04315- 2015-GE-18972)

\begin{tabular}{lll}
\hline No & 41 & 4,8 \\
\hline Accommodation other than family & & 65,9 \\
\hline Dorm & 27 & 4,9 \\
\hline Student house & 2 & 29,3 \\
\hline Relatives & 12 & \\
\hline Working & & 2,6 \\
\hline Yes & 22 & 97,4 \\
\hline No & 836 & 84,8 \\
\hline Pocket money & & 9,6 \\
\hline Enough & 728 & 5,6 \\
\hline Not enough & 82 & 100 \\
\hline More than enough & 48 & \\
\hline Total & 858 & \\
\hline
\end{tabular}

Table 1 shows the descriptive features of adolescents. $30,2 \%$ of them $(\mathrm{n}=259)$ are 15 and younger, 50,3 \% $(\mathrm{n}=432)$ are women, 49,7 \% $(\mathrm{n}=426)$ are men, 58,5\% $(\mathrm{n}=502)$ are vocational and technical school students. 50,7 \% $(\mathrm{n}=435)$ have $1-2$ siblings, 95,2 \% $(\mathrm{n}=817)$ live with their families, $65,9(\mathrm{n}=27)$ live in the dorm, 97,4 \% $(\mathrm{n}=836)$ do not work, 84,8 $\%(\mathrm{n}=728)$ have enough amount of pocket money. 


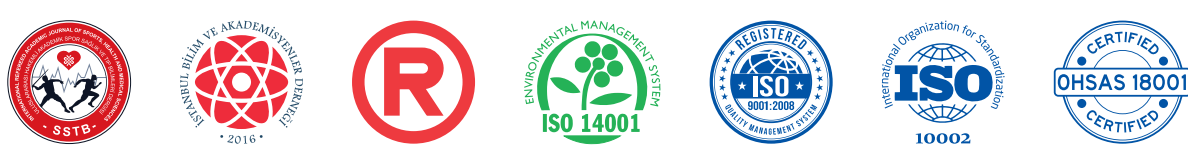

SSTB

www.sstbdergisi.com

International Refereed Academic Journal of Sports, Health and Medical Sciences

October - November - December Issue: 29 Fall Winter Semester Year: 2018

Uluslararası Hakemli Akademik Spor Sağlık ve Tıp Bilimleri Dergisi

Ekim - Kasım - Aralık Sayı: 29 Güz Kış Dönemi Yıl: 2018

ID:409 K:508

ISSN Print: 2146-8508 Online 2147-1711

(ISO 18001-OH-0090-13001706 / ISO 14001-EM-0090-13001706 / ISO 9001-QM-0090-13001706 / ISO 10002-CM-0090-13001706) (TRADEMARK)

(2015/04315- 2015-GE-18972)

\section{Table 2. Smoking and Water Pipe Use Among Adolescents}

\begin{tabular}{lll}
\hline Smoking and Water Pipe Use & $\mathrm{n}$ & $\%$ \\
\hline \multicolumn{1}{l}{ Smoking } & & \\
\hline Yes & 171 & 19,9 \\
\hline No & 687 & 80,1 \\
\hline Water Pipe Use & & \\
\hline Yes & 186 & 21,7 \\
\hline No & 672 & 78,3 \\
\hline Smoking in the Family & & \\
\hline Yes & 538 & 62,7 \\
\hline No & 320 & 37,3 \\
\hline Water pipe use in the family & & \\
\hline Yes & 137 & 16 \\
\hline No & 721 & 84 \\
\hline Total & 858 & 100
\end{tabular}

Smoking and hookah use among adolescents is studied and seen that $19,9 \%(n=171)$ smoke cigarette while $21,7 \%(n=186)$ use hookah. The rate of smoking in the family is $62,7 \%(\mathrm{n}=538)$, and hookah use in the family is $16 \%(\mathrm{n}=137)$ (Table 2).

Average score of adolescents from Perception Scale of Effects of Hookah use on Health is $61,97 \pm 11,12(\min =15, \max =75)$. Table 3 shows that average score of the total points from Perception Scale of Effects of Hookah use on Health is 4,12 which is equal to "I strongly agree" level.
Adolescents gave the answer "I strongly agree" to the items "Smoking water pipe affects lungs adversely" (item1), "Smoking water pipe increases the risk of cardiovascular disease" (item 4), "Exposure of nonsmokers to water pipe

smoke causes respiratory tract diseases" (item 5), "Oral infections (cancer, herpes, aphta etc.) may develop in water pipe smokers" (item 6), "Water pipe smoking cessation affects health positively"(item 8), "Water pipe contains nicotine" (item 9), "Diseases like flu and cold can be transmitted by sharing mouthpiece" (item 11), "Water pipe is not 
International Refereed Academic Journal of Sports, Health and Medical Sciences

October - November - December Issue: 29 Fall Winter Semester Year: 2018

Uluslararası Hakemli Akademik Spor Sağlık ve Tıp Bilimleri Dergisi

Ekim - Kasım - Aralık Sayı: 29 Güz Kış Dönemi Yıl: 2018 ID:409 K:508

ISSN Print: 2146-8508 Online 2147-1711

(ISO 18001-OH-0090-13001706 / ISO 14001-EM-0090-13001706 / ISO 9001-QM-0090-13001706 / ISO 10002-CM-0090-13001706) (TRADEMARK)

(2015/04315- 2015-GE-18972)

more innocent than the cigarette in terms of nicotine" (item 14), "Water pipe mouthpiece should never be shared" (item 15). The other items were answered as "I agree".

The average score from Brief Sensation Seeking Scale was $10,24 \pm 3,92(\min =4, \max =16)$.
Average score of the total points was 2,55 and it stood for "I agree", as seen in Table 4. It was seen that the adolescents gave the answer "I agree" to the whole items in Brief sensation Seeking Scale.

Table 3. An Assessment of the Relationship Between "Scale of Perception about the Effects of Water Pipe Smoking on Health" and "Brief Sensation Seeking Scale for Adolescents"

\begin{tabular}{llll} 
& $\begin{array}{l}\text { Scale of Perception about the Effects of Water Pipe Smoking on } \\
\text { Health }\end{array}$ & $\mathrm{N}$ \\
\hline & $\mathrm{R}$ & 0,001 & 858 \\
\hline $\begin{array}{l}\text { Brief Sensation Seeking Scale for } \\
\text { Adolescents }\end{array}$ & $-0,204$ & &
\end{tabular}

There was a statistically significant correlation between Perception Scale of Effects of Hookah use on Health and Brief Sensation Seeking Scale for Adolescents $(p<0,05)$. The study indicates a weak negative correlation $(r=-0.204)$. Adolescents get lower scores from Brief Sensation Seeking Scale, as they get higher score from Perception Scale of Effects of Hookah use on Health (Table 3).

\section{DISCUSSION}

It was found out that $21,7 \%$ of the adolescents who participated in the study used hookah, $19,9 \%$ of them smoked cigarettes (Table 2). Cakmak, in their study with high school students (2014: 25-43), stated that the rate of hookah use was 19,2\% and smoking ciga- rettes was 19,6\%. In another study with high school students, the rate of hookah use was 19 \% (Akter, 2011: 36-40). Between 2010 and 2012, the study called Monitoring the Future in the USA, among 5540 high school students revealed that the rate of hookah use was 18 \% (Palamar et al., 2014 :227-234). Another study in Canada in 2012 called National Youth Tobacco Survey showed that $10 \%$ of 31396 participants between the ages of 9-12 used hookah (Maziak et al., 2015: :i3-i12.). In 2012, National Youth Tobacco Survey in America, it was seen that $14.7 \%$ of 24658 secondary and high school students used hookah (Lee et al., 2015 :409-15). In United Arab Emirates 21\% of 560 secondary school students used hookah, $30 \%$ smoked both 
International Refereed Academic Journal of Sports, Health and Medical Sciences October - November - December Issue: 29 Fall Winter Semester Year: 2018

Uluslararası Hakemli Akademik Spor Sağlık ve Tıp Bilimleri Dergisi Ekim - Kasım - Aralık Sayı: 29 Güz Kış Dönemi Yıl: 2018 ID:409 K:508

ISSN Print: 2146-8508 Online 2147-1711

(ISO 18001-OH-0090-13001706 / ISO 14001-EM-0090-13001706 / ISO 9001-QM-0090-13001706 / ISO 10002-CM-0090-13001706) (TRADEMARK)

hookah and cigarette and $30 \%$ used hookah everyday (Shemmari et al., 2015: 427-430). In a study in Malesia $57,4 \%$ of 239 participants over 18 were found out to use any tobacco product, $50,7 \%$ only smoked cigarette, $5,9 \%$ only used hookah and $42 \%$ smoked both hookah and cigarette (Al Naggar et al., 2014: 10841-10846). The results show similarity with the literature.

The total score averages of adolescents from Perception Scale of Effects of Hookah use on Health were $61,97 \pm 11,12, \min =15, \max =75$. The average score from total scores of Perception Scale of Effects of Hookah use on Health was 4,12 which is equal to "I strongly agree". These results show that adolescents have good level of perception about effects of hookah use on health but they need to improve their knowledge on the subject.

Cakmak, (2014: 25-43) stated in their study that total score averages of adolescents from Perception Scale of Effects of Hookah use on Health was $58,47 \pm 1,25$, average score from scale item scores was 3,89 and it was equal to "I agree" level. In another study that Cakmak, (2014: 25-43) carried out in Tokat there were similar results.

Total score average from Brief Sensation Seeking Scale was $10,24 \pm 3,92, \quad \min =4$, $\max =16$. Average score of total scores from the answers to the scale items was 2,55 which contributes to "I agree" level as seen in Table 4. Adolescents gave the answer "I agree" to all the items in Brief Sensation Seeking Scale. These results indicate a high level of risk taking behaviour in adolescence.

There was a statistically significant correlation between the scores of Perception Scale of Effects of Hookah use on Health and Brief Sensation Seeking Scale $(p<0,05)$. Though not a strong one, this is a negative correlation $(r=-0,204)$. It was found out that the higher scores adolescents got from Perception Scale of Effects of Hookah use on Health, their scores from Brief Sensation Seeking Scale were lower (Table 3). Adolescents smoking hookah and cigarette had a high level of risk taking behaviour and a low level of perception about the effects of hookah use on health. As their perception on this subject increased, their tendency to risky behaviours decreased.

\section{CONCLUSION}

It was concluded that adolescents smoking hookah and cigarette had high levels of risk taking behaviours while their perception about effects of hookah use on health was low. The more their perception increased, the more their tendency to risky behaviours decreased.

\section{Funding sources}

None. 
International Refereed Academic Journal of Sports, Health and Medical Sciences October - November - December Issue: 29 Fall Winter Semester Year: 2018 Uluslararası Hakemli Akademik Spor Sağlık ve Tıp Bilimleri Dergisi Ekim - Kasım - Aralık Sayı: 29 Güz Kış Dönemi Yıl: 2018 ID:409 K:508

ISSN Print: 2146-8508 Online 2147-1711

(ISO 18001-OH-0090-13001706 / ISO 14001-EM-0090-13001706 / ISO 9001-QM-0090-13001706 / ISO 10002-CM-0090-13001706) (TRADEMARK)

\section{Competing interests}

None declared.

\section{REFERENCES}

AKTER, E., (2011). Adana İl Merkezindeki Lise Öğrencilerinde Tütün ve Tütün Mamüllerinin Kullanımı. Uzmanlık Tezi, Çukurova Üniversitesi, Tıp Fakültesi, Adana

AL-NAGGAR, R.A., SAGHIR, F.S.A., (2011). Water Pipe (Shisha) Smoking and Associated Factors Among Malaysian University Students. Asian Pacific J Cancer Prev, (12): 3041-3047

AL-NAGGAR, R.A., BOBRYSHEV, Y. V., ANIL, S., (2014). Pattern of Shisha and Cigarette Smoking in the General Population in Malaysia. Asian Pac J Cancer Prev, 15 (24): 10841-10846

ALVUR, M.T., CINAR, N., AKDURAN, F., DEDE, C., (2014). Fallacies about Water Pipe Use in Turksih University Students - What Might Be the Consequences? Asian Pac J Cancer Prev, 15 (5): $1977-$ 1980

ALZOHAIRY, M.A., (2012). Water Pipe \& Cigarette Smoking among Qassim University Male Students: Prevalence and Beliefs. International Journal of Health Sciences, Qassim University, 6(1): 45-57
ARAS, S., GUNAY, T., OZAN S, ORCIN, E,. (2007). İzmir İlinde Lise Öğrencilerinin Riskli Davranışları. Anadolu Psikiyatri Dergisi, (8): 186-196

BARDO, M.T., DONOHEW, R.L., HARRINGTON, N.G., (1996). Psychobiology of Novelty Seeking and Drug Seeking Behavior. Behav. Brain Res., 77: 23-43

BHAGABATY, S. M., KATAKI, A. C., KALITA, M., SALKAR, S., (2015). Community Based Intervention for Tobacco Cessation: A Pilot Study Experience, North East India. Asian Pac J Cancer Prev, 16 (2): 811-814

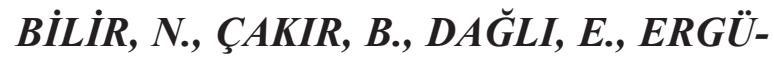
DER, T., ÖNDER, Z., (2010). Türkiye'de Tütün Kontrolü Politikaları, 33-42

CAKMAK, V., (2014). Adolesanların Nargilenin Sağlığa Etkileri Algıları. Sakarya Üniversitesi Sağl1k Bilimleri Enstitüsü, Yüksek Lisans Tezi, Sakarya

CELIK, E., TURAN, M.E., GUNGOR, H., (2014). Kısa Heyecan Arayışı Ölçeği: Ölçek Uyarlama, Güvenirlik ve Geçerlik Çalışması. 18. Ulusal Psikoloji Kongresi, s.207-208, Bursa

CELIK, Y., (2011). Nas1l? Biyoistatistik Bilimsel Araştırma SPSS. Yöntemlerin Uygulamalı ve Görsel Anlatımı. 1.Bask1: 195-196 
International Refereed Academic Journal of Sports, Health and Medical Sciences October - November - December Issue: 29 Fall Winter Semester Year: 2018

Uluslararası Hakemli Akademik Spor Sağlık ve Tıp Bilimleri Dergisi Ekim - Kasım - Aralık Sayı: 29 Güz Kış Dönemi Yıl: 2018 ID:409 K:508

ISSN Print: 2146-8508 Online 2147-1711

(ISO 18001-OH-0090-13001706 / ISO 14001-EM-0090-13001706 / ISO 9001-QM-0090-13001706 / ISO 10002-CM-0090-13001706) (TRADEMARK)

CINAR, N., CAKMAK, V., (2014). Is Waterpipe Smoking Becoming Increasingly Widespread Among the Youth? Asian Pac J Cancer Prev, 15 (18): 8005-8006

CRAWFORD, T.V., MCGROWDER, D.A., BARNETT, J.D., MCGAW, B.A., MCKENZIE, I. F., JAMES, L.G., (2012). Tobacco-Related Chronic Illnesses: A Public Health Concern for Jamaica. Asian Pacific J Cancer Prev, 13 (9): 4733-4738

DONOHEW, L., ZIMMERMAN, R.S., CUPP, P.S., NOVAK, S., COLON, S., ABELL, R., (2000). Sensation Seeking, Impulsive Decision-Making, And Risky Sex: Implications For Risk-Taking and Design of İnterventions. Pers. Indiv. Differences, 28: 1079-1091

HASSOY, H., ERGIN, I., DAVAS, A., DURUSOY, R., KARABABA, A.O., (2011). Sağlık Meslek Yüksek Okulu Öğrencilerinde Sigara, Nargile, Sarma Tütün Kullanımını Etkileyen Faktörlerin Belirlenmesi ve Öğrencilerin Sigara, Nargile, Sarma Tütüne Başlama ve Sürdürme Konusundaki Görüşleri. Solunum Dergisi, 13(2): 91-99

HEINO, A., VAN DER MOLEN, H.H., WILDE, G.J.S., (1996). Differences in Risk Experience Between Sensation Avoiders and Sensation Seekers. Pers. Indiv. Differences, 20: 71-79
HOYLE, R.H., FEJFAR, M.C., MILLER, J.D., (2000). Personality and Sexual RiskTaking: A Quantitative Review. J. Pers., 68: 1203-1231

IBRAHIMOV, F., SAHIN, I, EMINAGA, F., FEYZIOGLU, K., METIN, B.C., ASLAN, D., (2012). Nargile İçicilerinin Bazı Özellikleri ve Ekspiryum Havasında Karbon Monoksid (CO) Düzeylerinin Saptanması. Gülhane Tip Dergisi, (54): 49-56

KUNTZ, B., LAMPERT, T., (2015). Waterpipe (Shisha) Smoking Among Adolescents in Germany: Results of the KIGGS Study: First Follow-Up (KIGGS Wave 1). Bundesgesundheitsblatt Gesundheitsforschung Gesundheitsschutz, 58(4/5): $467-473$

LEE, Y.O., HEBERT, C.J.B.A., NONNEMAKER, J.M., KIM, A.E., (2015). Youth Tobacco Product Use in the United States. Pediatrics, 135(3): 409-15. doi: 10.1542/ peds.2014-3202. Epub 2015 Feb 2

MAZİAK, W., (2013). The Waterpipe: An Emerging Global Risk For Cancer. Cancer Epidemiol, 37 (1): 1-4. doi:10.1016/j. canep.2012.10.013

MAZİAK, W., TALEB, Z.B., BAHELAH, R., ISLAM, F., JABER, R., AUF, R., SALLOUM, R.G., (2015). The Global Epi- 
International Refereed Academic Journal of Sports, Health and Medical Sciences October - November - December Issue: 29 Fall Winter Semester Year: 2018 Uluslararası Hakemli Akademik Spor Sağlık ve Tıp Bilimleri Dergisi Ekim - Kasım - Aralık Sayı: 29 Güz Kış Dönemi Yıl: 2018 ID:409 K:508

ISSN Print: 2146-8508 Online 2147-1711

(ISO 18001-OH-0090-13001706 / ISO 14001-EM-0090-13001706 / ISO 9001-QM-0090-13001706 / ISO 10002-CM-0090-13001706) (TRADEMARK)

demiology of Waterpipe Smoking. Tob Control, 24: i3-i12. doi:10.1136/tobaccocontrol-2014-051903

NEWCOMB, M.D., MCGEE, L., (199)1. Influence of Sensation Seeking on General Deviance and Specific Problem Behaviors from Adolescence to Young Adulthood. J. Pers. Soc. Psychol., 61: 614-628

\section{OKAGUA, J., OPARA, P., ALEX HART,}

B.A., (2015). Prevalence and Determinants of Cigarette Smoking Among Adolescents in Secondary Schools in Port Harcourt, Southern Nigeria. International Journal of Adolescent Medicine and Health, 28(1): 19-24 DOI: 10.1515/ ijamh-2014-0066

OKDEMİR, S., (2013). Nargile İçimine Bağ11 Karboksihemoglobin Seviyelerinin Değerlendirilmesi. Gazi Üniversitesi Tıp Fakültesi, Uzmanlık Tezi, Ankara

ÖZCEBE, H., (2002). Birinci Basamakta Adolesan Sorunlarına Yaklaşım. Sürekli Tıp Eğitim Dergisi, 11(10): 374-377

PALAMAR, J.J., ZHOU, S., SHERMAN, S., WEITZMAN, M., (2014). Hookah Use Among US High School Seniors, Pediatrics, 134: 227-234

PALMGREEN, P., DONOHEW,L., LORCH, E.P., HOYLE, R.H., STEPHENSON,
M.T., (2001). Television Campaigns and Adolescent Marijuana Use: Tests of Sensation Seeking Targeting. Am. J. Public Health, 91: 292-295

PATEL, D., KASSIM, S., CROUCHER, R., (2012). Tobacco Promotion and Availability in School Neighborhoods in India: A Cross-Sectional Study of Their Impact on Adolescent Tobacco Use. Asian Pacific J Cancer Prev, (13): 4173-4176

PAULMAN, P.M., PAULMAN, A.A., HARRISON, J.D., (2011). Taylor Aile Hekimliği El Kitabı. 3 rd edit, Çeviri Edit: Basak, O., \& Demirag, S. A. Güneş Tip Kitabevleri, Ankara

PELTZER, K., PENGPID, S., (2014). Tobacco Use, Beliefs and Risk Awareness in University Students from 24 Low, Middle and Emerging Economy Countries. Asian Pac J Cancer Prev, 15 (22): 10033-10038

SEZER, R.E., PICAK, Y.K., (2011). Tütün Mücadelesi İçin Yeni Bir Tehdit: Aromatik Nargile. Cumhuriyet Tip Dergisi, (33): 133-143

SHAIKKH, R.B., et al., (2012). Acute Effects of Dokha Smoking on the Cardiovascular and Respiratory Systems among UAE Male University Students. Asian Pacific J Cancer Prev, (13): 1819-1822 
SSTB

www.sstbdergisi.com

International Refereed Academic Journal of Sports, Health and Medical Sciences October - November - December Issue: 29 Fall Winter Semester Year: 2018

Uluslararası Hakemli Akademik Spor Sağlık ve Tıp Bilimleri Dergisi

Ekim - Kasım - Aralık Sayı: 29 Güz Kıș Dönemi Yıl: 2018 ID:409 K:508

ISSN Print: 2146-8508 Online 2147-1711

(ISO 18001-OH-0090-13001706 / ISO 14001-EM-0090-13001706 / ISO 9001-QM-0090-13001706 / ISO 10002-CM-0090-13001706) (TRADEMARK)

SHEMMARI, N.O., SHAIKKH, R.B., CREEDHARAN, J., (2015). Prevalence of Dokha Use among School Students in Ajman, United Arab Emirates. Asian Pacific J Cancer Prev, 16 (2): 427-430

STACY, A.W., NEWCOMB, M.D., BENTLER, P.M., (1993). Cognitive Motivations and Sensation Seeking as Long-Term Predictors of Drinking Problems. J. Soc. Clin. Psychol.,12: 1-24

STEPHENSON, M. T., HOYLE, R.H., PALMGREEN, P., SLATER, M.D., (2003). Brief measures of sensation seeking for screening and large-scale surveys. Drug and Alcohol Dependence, 72: 279 286

STEPHENSON, M.T., MORGAN, S.E., LORCH, E.P., PALMGREEN, P., DONOHEW, L., HOYLE, R.H., (2002).
Predictors of Exposure from an Anti-Marijuana Media Campaign: Outcome Research Assessing Sensation Seeking Targeting. Health Commun., 14: 23-43

TELEF, B.B., (2014). Ergenlerde Olumlu ve Olumsuz Duygular ile Riskli Davranışlar Arasındaki İlişkinin İncelenmesi. Kastamonu Eğitim Dergisi, 22(2): 591-604

ZUCKERMAN, M., BALL, S., BLACK, J., (1990). Influences of Sensation, Gender, Risk Appraisal, and Situational Motivation on Smoking. Addict. Behav., 15: 209-220.

ZUCKERMAN, M., KUHLMAN, D.M., JOIREMAN, J., TETA, P., KRAFT, M., (1993). A Comparison of Three Structural Models for Personality: The Big Three, the Big Five, and the Alternative Five. J. Pers. Soc. Psychol., 65: 757-768 